\title{
Modern moral reinterpretation of Jesus and its value to the philosophy of religion
}

\section{Antoni TORZEWSKI*}

\begin{abstract}
The moral reinterpretation of Jesus conducted by Kant, Lessing and Feuerbach, is an interesting matter when it comes to the philosophy of religion. The abovementioned German philosophers claimed that Jesus ought to be understood only as a moral archetype and a revolutionist in morality. This concept arose on the grounds of moral religion which was one of the most interesting ideas of the Enlightenment. Thus, exploring this moral reinterpretation of Jesus is just an excuse to study the concept of moral religion. Despite the fact that this idea is no longer current, it has immense influence on the contemporary philosophy of religion. Therefore, understanding the concept of moral religion can broaden the context of the contemporary discussion.
\end{abstract}

\section{KEYWORDS}

morality; ethics; religion; moral religion; contemporary philosophy; Jesus; Immanuel Kant; Gothold Ephraim Lessing; Ludwig Feuerbach; reinterpretation; German philosophy Enlightenment

* Lic., postgraduate student of philosophy at the Kazimierz Wielki University in Bydgoszcz, philosophy teacher. E-mail: antoni.torzewski@gmail.com. 
The Enlightenment gave us, apart from outstanding works on ontology or epistemology, also a concept of moral religion (which is special in its essence). ${ }^{1}$ Many of the Enlightenment's thinkers tried to come up with a project of religion which would derive from reason alone and also would be limited to it. ${ }^{2}$ Consequently written were books like: Immanuel Kant's Religion within the bounds of bare reason, Gotthold Ephraim Lessing's Education of the buman race or a bit latter but expressing similar tendencies in capturing some of the aspects of religion: Ludwig Feuerbach's The essence of Christianity. I will, in fact, focus on those books in this paper. I wish to show how, on the basis of the concept of moral religion, Jesus was presented and interpreted. Since all of the philosophers mentioned above, when they reflected on religion, had Christianity in mind, I presume that showing in what way Jesus appeared to them may help understand their theories of religion. I also wish to refer to the place which moral religion theory occupies in contemporary philosophy, and to show how and by whom it was criticized. Of course, the topic of this paper is very broad and should be discussed more extensively. Therefore, the following text should be treated only as a contribution to that topic or as an invitation to think about it on a larger scale.

Kant, Lessing, Feuerbach, and many other thinkers (whom I will subsequently mention) point out some sort of falseness in Christianity. They claim that the most of what came after Jesus is incompatible with his teachings. Ipso facto they blight not only the contemporary (to them) understanding of Christianity but even the teachings of the majority of the Church Fathers or the Holy Bible itself. All the mentioned philosophers proclaimed that the figure of Jesus itself and its meaning to the people was wrongly interpreted and instead of focusing on the new morality that was brought by Jesus, believers

${ }^{1}$ The concept of moral religion is one of many attempts to interpret religion. It stands side by side with Émile Durkheim's totemism, Sigmund Freud's psychoanalytic interpretation, Karl Marx's historical materialism, Richard Dawkins' naturalism etc. Each theory had a different explanation of what religion is really about. Durkheim claimed that religion is just an expression of human social bonds, Freud understood the essence of religion as connected with sexual drives, Marx treated it as an "opium for the people", whereas Dawkins claimed that religion is an expression of a collective delusion. While the concept of moral religion often (but not always) reduces religion to its moral aspect - see Wszołek, 2004.

2 The endeavor to formulate a concept of religion within the limits of reason could occur because of science's development, thanks to which (allegedly) people were able to undermine and discredit religious dogmas (transcendence) as impossible to prove. Taylor in A Catholic modernity claims that also in today's world there is no place for transcendence, although it is not a result of science's development, but for moral reasons: "The thesis I'm presenting here is that it is by virtue of its postrevolutionary climate that Western modernity is very inhospitable to the transcendent. This, of course, runs contrary to the mainline Enlightenment story, according to which religion has become less credible, thanks to the advance of science" (Taylor, 1999: 25). 
turned to cult and ritual, ${ }^{3}$ which, as they claim, are redundant and constitute only a "superstructure" on the "building" of religion. Nonetheless, every one of them, despite agreeing on this general claim about falsifying the figure of Jesus, in their own way presented what it exactly means and in what manner we ought to understand it.

We will begin with Kant, because his theory seems the most insightful and the most extensive as well as being the most discussed theory in today's philosophy of religion when compared to Lessing's and Feuerbach's. As Stephen R. Palmquist states in the opening section of his article: "Few if any past philosophers have had more influence on contemporary theology and philosophy of religion than Immanuel Kant" (Palmquist, 2012). Then we will cover Lessing as a kind of supplement to Kant's theory, a supplement which expands Kant's religion mostly within the historical aspect (something not developed that much in Kant's theory of religion). ${ }^{4}$ Thirdly, we will discuss Feuerbach's project of moral religion, because it is, at some point, different from Kant's and Lessing's and also because Feuerbach was later than the other two.

The theory of religion constructed by Kant was nothing new, since he was simply following the idea — initiated much earlier — of creating a project of natural religion..$^{5}$ The main notion of Kant's "pure rational religion" is to point out the moral - and only moral — character of religion (by religion Kant

${ }^{3}$ Cult and ritual are means to worship God. When they are understood that way, none of the mentioned philosophers would argue to reject them. None of them would also deny the need to worship God. However, their concept of cult and ritual is different - it is no longer a mean of worship, but only a pseudo-service, false knowledge, because to truly worship God is to live a morally good life.

${ }^{4}$ It is important to mention that, although we will treat Lessing as a supplement to Kant, The education of the buman race was published 12 years before Kant's Religion within the bounds of bare reason. Therefore, historically speaking, Lessing was not influenced by Kant and his book was not a supplement to his theory. In this paper, however, we will try to look at this in the perspective of ideas within which Lessing's philosophy of religion could be viewed as a supplement to Kant's.

${ }_{5}$ The precursor of natural religion thought was Erasmus of Rotterdam. As one of the first, he criticized the clergy and superstition in the Catholic Church; for example in the book The praise of folly (see Erasmus, 1913: 81, 85, 120, 133, 136). He also focused on the moral and rational character of religion and he exhorted to return to it. For example: "whereas if some scurvy Wise fellow should step up, and speak things as they are, as, To live well is the way to dye well; The best way to get quit of sin is to add to the money thou giv'st, the Hatred of sin, Tears, Watchings, Prayers, Fastings, and amendment of life; Such or such a Saint will favour thee, if thou imitatest his life; these, I say, and the like, should this Wise man chat to the people, from what happiness into how great troubles would he draw 'em ?” (Erasmus, 1913: 85). 
usually means Christianity). This is the typical way of presenting Kant's theory of religion. Although when we go deeper into it, we can see the uniqueness of Kant in the context of other philosophers who postulated natural religion. ${ }^{6}$ Since every one of them established their concepts on reducing religion to morality, whereas Kant strived in another direction - he elevated morality to religion. ${ }^{7}$ According to the German philosopher, there is something divine in morality - or even not so much in morality as in the possibility of good moral action. Consequently Jesus is portrayed in Kant's theory as a moral archetype, as a teacher who presents a new morality and also as the one whose death made us, humans, free (that is act on the grounds of the good). ${ }^{8}$ To be more specific - Jesus abolishes the given Old Testament morality based on a reward and punishment principle.

${ }^{6}$ For more on Kantian religion - see the extensive work of Palmquist covering most of the aspects concerning Kant's view of pure religion, including: Christology, morality, and the role of the (pseudo-)service to God (Palmquist, 2016). See also Chris L. Firestone and Nathan A. Jacobs's defense of Kantian religion covering, among others, the non-reductionistic perspective (Firestone \& Jacobs, 2008).

7 This claim originates from Palmquist's 1992 article called Does Kant reduce religion to morality? in which the author argues that Kant's view of religion is compatible with "open-minded" Christianity and not-explicitly answers the question used in the title by asking "Did Jesus and the writer of the Bible reduce religion to morality?" (Palmquist, 1992: 148) and quoting the passage from the Bible about the essence of the God-human relationship, which is a morally good life. Among those who also support Palmquist's thesis one can find: Firestone and Jacobs's In defense of Kant's religion (Firestone \& Jacobs, 2008) and Lawrence R. Pasternack's Routledge philosophy guidebook to Kant religion within the boundaries of mere reason (Pasternack, 2013). In Poland, one of those in favor of the thesis that, as far as Kant is concerned, we are dealing with elevating morality to religion and not reducing religion to morality would be, for example, Henryk Borowski who writes in his book Kantowska filozofia religii: "Morality leads to religion in a sense that because of giving the highest rank to moral duties, we cause morality to become in a way something more than it is" (Borowski, 1986: 145) [the translation of all books written in Polish have been done by the author]. But as we can see the mentioned thesis is directly defended in Maciej Chlewicki's book Kant a problem filozofi religii, where the author states: "that Kant takes morality as a base and tries to make 'religion' from it, he wants to elevate it in a sense to the rank of religion, thus to make more of it than it is in reality" (Chlewicki, 2012: 121). Or in another place: "Kant is not only reducing religion to morality, but - in a sense the opposite - he elevates morality to the rank (honour) of a religion" (Chlewicki, 2012: 21). In the article Kant, Ficbte i wczesny Hegel o religii moralnej the author even claims, that: "ethics becomes in this concept like an omnipotent moral lawgiver that is God" (Chlewicki, 2011: 230). Foregoing claims could indicate the unique character of Kant's thought in the context of other Enlightenment theories of natural religion, which were in fact reducing religion to morality, and not - like in Kant's philosophy — elevating morality to religion, not looking for anything divine in it.

${ }^{8}$ For more on the subject of Kant and Jesus - see Palmquist's insightful article (Palmquist, 2012) which also covers the non-reductionistic interpretation of Kantian religion. See also: Thomas, 1970 and a response to that article - Carmichael, 1973. 
[I]n that [Judaic - A.T.] legislation they [the laws - A.T.] have not been given at all with the demand on one's moral attitude in obeying them (wherein Christianity later posited the main work), but have been directed absolutely only to the external observance (Kant, 2009: 140). ${ }^{9}$

Jesus also presents a new morality which, unlike the morality of the Jews, focuses more on the motives of actions and is expressed in the love commandment, for love refers more to the internal sphere, the sphere of motives, than to the external practice: the results of actions. The moral duty of love to one's neighbor is imposed to a human being and manifests itself in the motives of one's action. The love commandment also makes Christianity a moral religion, and:

according to the moral religion (and among all the public religions that ever there have been, the Christian alone is of this sort), it is a principle that everyone must do as much as is in his powers in order to become a better human being (Kant, 2009: 59).

Furthermore, Kant points out the human nature of Jesus by showing him as a moral archetype and savior. Jesus is a man, thus he is influenced by the same drives and desires as common people, but in spite of that he can still be a moral ideal. That is why people can, so to speak, identify with him. That means that an ordinary human being also can get closer to this moral ideal and is capable of good deeds. If the moral archetype is God (who has no human nature), an ordinary human being realizes that they could never be close to equal with him within a moral or any other sphere. Jesus's human aspect is emphasized by Kant also in the context of crucifixion. Because Jesus as a man died on the cross, he presented the possibility of freedom. That kind of interpretation of Jesus, as Kant shows it, is very beneficial and constitutes a solid argument for the concept of moral religion. If Jesus is a spokesman of a new morality, then why would Christians not focus exactly on that fact? Thus, the Church (as a Christian community), according to Kant, should primarily remind us of following Jesus, that is of acting for the same reasons as he did. Kant states that he is "an example to follow for every man" and further:

through the example he gives of this principle (in the moral idea) he opens the gate of freedom to all who, like him, want to die unto everything that keeps them fettered to life on earth to the detriment of morality (Kant, 2009: 93).

However, instead of following Jesus, the Church is more focused on pure cult and ritual which are, according do Kant, morally neutral. ${ }^{10}$ When we read

${ }^{9}$ Of course, the morality Kant is presenting makes sense only when we assume that it is internal motives that are crucial when assessing moral activities. Whereas when the results of those activities are not the subject of assessment, they are not important.

${ }^{10}$ Chlewicki states that the main idea for Kant was "moral religion [...] and because of it, every - in this sense understood as non-authentic - manifestation of piety did not deserve, 
some of the words of the German philosopher, we could even come to the conclusion that he thinks of pure cult and ritual as of something that belongs to the stupid, since

the human being who uses actions-actions that by themselves contain nothing pleasing to God (nothing moral)-nonetheless as means for gaining God's direct pleasure in him and, thereby, the fulfillment of his wishes, is under the delusion that he possesses an art of bringing about a supranatural effect through entirely natural means. Attempts of this sort are usually called magic (Kant, 2009: 197).

Cult and ritual, according to Kant, dominate in the modern world and are an expression of "delusions" and "pseudo-service" to God. Practices like penance, pilgrimage or attending the Holy Mass are morally neutral and far from praising the glory of God. "The more useless such self-torments are and the less their purpose is the universal moral improvement of the human being, the holier they seem to be" (Kant, 2009: 187). One can please God only by a good moral deed and nothing else. Thus, faith should sort of return to the original state, to the figure of Jesus and focus only on the morality he speaks of, and then try to follow him and not, as Kant puts it, to "do magic".

The assumption about the moral essence of religion was also made by Lessing. He claimed, like Kant, that moral development had no need for revelation. For this can only speed up the process. However, his concept was different from Kant's primarily because religion — understood as a moral development — was considered to be historical. The author of Education of the buman race distinguished three stages of moral development in history: 1) child age; 2) boy age; 3) man age. There is also a sort of pre-stage in Lessing's theory, which is polytheism. However, the German philosopher does not pay much attention to that matter, thus we can assume that moral development is possible only in monotheistic religions.

The first stage of moral development within the human race was the Judaic religion, the religion of Israel, which is characterized by Lessing as displaying the most primitive, rough morality based on the reward and punishment

in the eyes of the philosopher, to be called true religion" (Chlewicki, 2012: 144). Of course, what Chlewicki means has to be piety understood as a sole focus on just cult and ritual, because piety could have a positive role in Kant's philosophy of religion but only when its place (that is - piety comes after morality as a kind of bonus and not before it as it is often perceived) is well recognized. 
principle. The German philosopher treats the Jews as a primitive, bearish people who are incapable of abstract thinking. ${ }^{11}$ He asks:

what kind of moral education was such a primitive people, so incapable of abstract thoughts, and still so completely in a state of childhood, ready for? None other than that appropriate to the age of childhood: education through direct physical punishment and rewards (Lessing, 1908: §16).

What is important, reward and punishment were conceived in temporal categories - here, in this life, in this world there will be justice for one's actions. Jews were not ready to accept any more noble morality. They were exactly at that particular stage of moral "sensitivity" development which fruited in the morality of the Old Testament.

Thus, education and revelation meet here, too. God was still unable to give his people any other religion, any other law, than one through whose observance or non-observance they hoped, or feared, to be happy or unhappy here on Earth. For their vision did not extend beyond this life (Lessing, 1908: §17).

The knowledge obtained during contact with other nations like Persia or Egypt, among other things, led to the start of forming in the minds of some of the Jews the need for more noble motives of actions than just the fear of God's rage or the hope of reward. Whereas the role of the Old Testament as a source of moral commandments was starting to lessen, since "every primer is only for a certain age. To persist in using a primer longer than recommended, when a child has outgrown it, is harmful” (Lessing, 1908: §51). Despite that, the German philosopher directs attention to certain parts of the Old Testament in which one can find some clues about the concept of the immortality of the soul. An exemplification of which is "the divine threat to inflict the sins of the fathers on the children down to the third and fourth generation" (Lessing, 1908: §44). Based on that piece, the reader is able to see for themselves a context which extends beyond their own particular existence. However, the immortal soul theory is not directly stressed.

That way, according to Lessing, human kind was preparing itself for the oncoming of Jesus, who revolutionized morality by his arrival and teachings he highlighted different, more noble motives of actions, and also relocated justice, since it would be done in "the future life". Lessing underlines the

11 We can see, at this point, the seeds of anti-Semitism in German thought. This is not only in the case of Kant, but also the other mentioned philosophers, like Lessing and Feuerbach. They all speak of Jews in a very pejorative manner. However, there are also authors who would reconsider those accusations towards Kant by pointing, among others, out the relations he had with Moses Mendelssohn or the matter of the (in)compatibility of his theory of religion with Judaism. See for example: Munk, 2006; Axinn, 1968. 
teachings about immortality of the soul, thanks to which relocating justice from the worldly to the heavenly sphere is possible. Before Jesus's arrival it had been not possible because

the doctrine of the immortality of the soul and the associated doctrine of punishment and reward in a future life are not found therein (Lessing, 1908: §22).

Lessing, like Kant, considered Jesus to be an educator of the new morality, as a moral archetype, ${ }^{12}$ but also stressed the role of his students in shaping and falsifying Christianity. "A better Instructor must come - writes Lessing and rip the exhausted primer from the child's hands. Christ came" (Lessing, 1908: §53). This "exhausted primer" is the Old Testament and its moral teachings. Jesus is giving us a new, more noble morality, thanks to which the human race can begin a new stage of the development of religion. As mentioned before, it is connected with the teachings about the immortality of the soul. Jesus, according to Lessing, was "the first reliable, practical teacher of the immortality of the soul” (Lessing, 1908: §58). But the disciples of Jesus

transferred other doctrines [to the doctrine of the immortality of the soul - A.T.] whose truth was less evident, whose benefits were less substantial (Lessing, 1908: §63).

Like Kant, Lessing claims that the contemporary Church which is built on the teachings of Jesus's disciples, is a falsification of the true purpose of his arrival. However, it is not a direct critique of cult and ritual - as it is in Kant's theory - but just a highlight on some "other teachings", a distraction from the essence which is the new morality presented by Jesus.

Lessing, in contrast to Kant, does not recommend a return to the "true teachings" of Jesus, rejection of cult and ritual, but only claims that it will happen on its own when humankind understands the essence of the morality presented by Jesus and then will abandon all that is redundant. This is because, according to Lessing, the revelation contains the truth (about morality) which humankind can also come to understand without any help from the revelation, but only later. Thus, along with Jesus's arrival a new revelation was given to humankind, but after some time, when the reason of humankind has developed enough, the truths contained in the revelation will be presented by reason and reason only. Then some "redundant" aspects of religion (like, for example, cult

12 Rudolf Otto does also, in a similar way, speak of Jesus as of a moral revolutionary through an analysis of Saint Paul's words: "Here Paul has penetrated to the heart of the matter, breaking definitely with the older religion and seizing unerringly upon the very principle and essence of the new. And this principle and essence was the same for the first fisher men by the Lake of Galilee and has remained one and the same throughout the whole history of Christianity. With it is given the new attitude to Sin and Guilt, to Law and to Freedom" (Otto, 1936: 172). 
and ritual) will be rejected. And then also the third stage of the development of religion will be realized. ${ }^{13}$

The general motto of Feuerbach's theory of religion is the claim: "theology is anthropology". On the basis of this thesis the German philosopher builds a whole interpretation of religion as a development of human self-understanding, for a human - understood as a species - develops consciousness across history and thanks to this begins to see that religion is not about God or angels, not about an "afterlife", but about themselves, about humans as a species-being. ${ }^{14}$ Feuerbach writes:

Hence the historical progress of religion consists in this: that what by an earlier religion was regarded as objective, is now recognised as subjective; that is, what was formerly contemplated and worshipped as God is now perceived to be something human (Feuerbach, 1881: 33).

When we read these words, we can get an impression that Feuerbach's concept is very similar to Lessing's. Since the author of Education of buman race also claims that along with the moral development of the human race, a human being starts to see that the thing they previously considered as a truth of revelation is in fact a truth of reason. It is enough to put "something objective" instead of the "truth of revelation" and instead of the "truth of reason" "something subjective" and we are extremely close to Feuerbach. However, the author of The essence of Christianity focuses on the development of reason, thanks to which we can, over time, abolish religion. In contrast, Lessing points out the moral development, thanks to which religion just takes another form. Lessing does not claim that God is in some way a human creation, but

${ }^{13}$ I think that this third stage of religious development is in fact the same thing as Kant's theory of religion, since in Lessing's concept (concerning the third stage of religion development) there is nothing we could not find in Kant's. The Koenigsberg philosopher thinks that religion ought to become a moral service to God, that every man should choose because of the good itself and not because of the possible rewards or punishments, "for, moral faith must be a free faith based on pure attitudes of the heart" (Kant, 2009: 128). If that happens, God's kingdom on earth will be constituted. Lessing also makes claims like this. Borowski would support the thesis about filling in Lessing's theory with Kant's concept. He writes: "There was a need - according to Lessing - for a new revelation; a new scripture presenting - deeper than previous - principles of a moral action. Thus, there is a need [...] for a new Gospel. Kant's philosophy of religion and his ethics constitute in fact this new scripture" (Borowski, 1986: 163).

14 Trias accurately captures the essence of Feuerbach's concept of religion - see Trias, 1998: 97. 
only that we can reach the truth of revelation by our reason - which besides indicates the objective and true character of the truth of revelation. Thus, Feuerbach is more likely to point out the regress of religion, while Lessing its development.

For the author of The essence of Christianity God is a human's projections of a species notion of human essence. He is also all of what a human as an individual being negates in themselves. Thus, God is perfect, infinite, good, omnipotent, etc. While a human on the contrary - they are imperfect, finite, sinful, weak, etc.

God and man — writes Feuerbach — are extremes: God is the absolutely positive, the sum of all realities; man the absolutely negative, comprehending all negations (Feuerbach, 1881: 33).

A cult focused on God seems necessary to this imperfect humanity, but in fact it is only an expression of the arrogance of human kind which worships its own species essence on the pretext of worshiping a being "not from this world", a being ontologically different. However, along with the development of human self-awareness, a human being starts to realize the "true" nature of God, and thus God is no longer needed. They see,

that the consciousness of God is nothing else than the consciousness of the species; that man can and should raise himself only above the limits of his individuality (Feuerbach, 1881: 270).

Here the religion strives to a self-denial. It is worth mentioning the notion crucial for Feuerbach - the notion of love. ${ }^{15}$ Love is not only what Jesus embodies, but also something that can make religion become universal. The claim of universality - of which Kant also speaks so much - is the subject of long speculations for Feuerbach. His thesis is that Christian love is not "true" love, since it refers only to the potential fellow believers or even broader - only to the people who profess the Christian faith. However, love ought to be universal, that is not limited to a certain group of people, but should embrace them all.

But Christianity has not made love free; it has not raised itself to the height of accepting love as absolute. And it has not given this freedom, nay, cannot give it, because it is a religion, - and hence subjects love to the dominion of faith. Love is only the

${ }^{15}$ Here we come across a difficulty, since the German philosopher uses the notion of love many times. Unfortunately, it is not clear enough what he means by that. Some times "love" refers to feelings, irrational powers, but the other times it is associated with reason and morality. When Feuerbach criticizes rationalism in religion, he uses the notion of love as an opposite to "rationality". There is a call to return to feelings, to what is irrational, it seems to God himself and some sort of mysticism in the notion of love. 
exoteric, faith the esoteric doctrine of Christianity; love is only the morality, faith the religion of the Christian religion (Feuerbach, 1881: 263).

Although, a religion in which the law of love (but universal love) would be the only law, would be a religion which is desired, a religion which is true. However, on the grounds of Feuerbach's theory that kind of religion is not possible, since religion is always in conflict with love, it always tries to be "higher". As we will see an excuse for Feuerbach to reflect on love is the figure of Jesus as a love-giver.

As far as the Christian religion is concerned, the key figure - on which the German philosopher focuses - is Jesus. Feuerbach in his reflections about the essence of religion depicts Jesus (among others) with the transition between Judaism and Christianity which "has spiritualized the egoism of Judaism" (Feuerbach, 1881: 121). However, he is more focused on the human aspect of Jesus than just on his moral teachings. God who suffers and is visible is the most important for the German philosopher in the context of his theory of religion. Jesus is also the one who - at this point Feuerbach would agree with Kant and Lessing - represents a moral archetype. Furthermore, superstitions and sophistry are connected with the Holy Bible, since every written word always leads to the Bible. Speaking about Feuerbach, not only are the things that happened after Jesus a falsification of religion, because religion as a whole represents a falsification of its essence, i.e., religion represents nothing supernatural, just something falsely elevated to the rank of supernaturality, but in fact something entirely human. At this point Feuerbach goes much further than Kant or Lessing. Understood like that, Jesus is also only some sort of a symbol of human power or, as Feuerbach puts it, "an objectified human essence". The crucifixion and the suffering of Jesus are a symbol of

not only moral, voluntary suffering, the suffering of love, the power of sacrificing self for the good of others; it represents also suffering as such, suffering in so far as it is an expression of possibility in general (Feuerbach, 1881: 60).

This in fact is the essence of Jesus's arrival, this makes him a savior,

he is the joyful certainty of feeling that its wishes hidden in God have truth and reality, the actual victory over death, over all the powers of the world and Nature, the resurrection no longer merely hoped for, but already accomplished (Feuerbach, 1881: 144).

Jesus as a personal God, as a visible and suffering God is

the highest confidence, the highest self-enjoyment, the highest consolation of feeling; for only in the blood of Christ is the thirst for a personal, that is, a human, sympathising, tender God allayed (Feuerbach, 1881: 147). 
As a moral archetype and a love-giver Jesus shows that who

loves man for the sake of man, who rises to the love of the species, to universal love, adequate to the nature of the species he is a Christian, is Christ himself. He does what Christ did, what made Christ Christ (Feuerbach, 1881: 269).

Jesus is important to Feuerbach because of the suffering and love, and love is, according to the German philosopher, morality. ${ }^{16}$ When we conceive Jesus in this way, we also come to the conclusion that the moral aspect of religion is crucial, that Jesus is primarily a moral archetype, a love-giver, a provider of the love commandment. Though, the word which describes his life and teachings is false.

the necessary consequence of a faith in which an historical book, necessarily subject to all the conditions of a temporal, finite production, is regarded as an eternal, absolute, universally authoritative word, is - superstition and sophistry (Feuerbach, 1881: 209).

It is because we do not know if we should read this "book" literally, interpret it or criticize it. As we see, not only Kant and Lessing accuse the disciples of a falsification of the teachings of Jesus. Also, such a tendency appears on the grounds of Feuerbach's theory.

\section{IV}

The tendency to reinterpret the figure of Jesus, which I have shown by the examples of Kant, Lessing and Feuerbach, represents the eighteenth- and nineteenth-century striving to demythologize religion. ${ }^{17}$ However, it seems that in Kant's philosophy the case is not the demythologization of religion, but rather granting morality a sacrum character. ${ }^{18}$ This would be the difference be-

${ }^{16}$ In one of the two senses in which we can understand the notion of love on the ground of Feuerbach's theory.

${ }^{17}$ Demythologization and the critique of religion made by the eighteenth- and nineteenthcentury thinkers can also be applied in contemporary philosophy. Taylor claims that postmodern humanism takes, in some aspects, a form similar to the religion in the Enlightenment era. "A lofty humanism posits high standards of self-worth and a magnificent goal to strive toward. It inspires enterprises of great moment. But by this very token it encourages force, despotism, tutelage, ultimately contempt, and a certain ruthlessness in shaping refractory human material - oddly enough, the same horrors that Enlightenment critique picked up in societies and institutions dominated by religion, and for the same causes" (Taylor, 1999: 33).

${ }_{18}$ As we have mentioned before, Chlewicki writes about that in his book Kant a problem filozofi religii. But it is worth citing another contemporary thinker who points out that in Kant's theory Christianity and pure morality are the same, since "pure morality and Christianity are indissociable in their essence and in their concept. If there is no Christianity without pure morality, it is because Christian revelation teaches us something essential about the very 
tween Kant and the others. It is worth mentioning other philosophers who, by criticizing religion, expressed the mentioned tendency. These included: David Hume, Voltaire, Jean-Jacques Rousseau, Johnn Gottlieb Fichte, Georg Wilhelm Friedrich Hegel and later Rudolf Otto.

The demythologization of religion was based primarily on striping it of its sacral aspect. But what would replace the old sacrum? For many, it could be morality. That is why Jesus - in the mentioned interpretations - is deprived of his sacredness, he is no longer conceived as the Redeemer and Savior. However, what is stressed is his moral teaching. And morality for most (except Kant) is just a "human thing", worldly thing. In this particular aspect we can speak of the desacralization of religion. But when religion is lowered to the "human level", cult and ritual become redundant ${ }^{19}$ (which, besides, contributed much to the start of the critique of religion).

The reflection on the relations between religion and morality which was a crucial problem of Enlightenment and post-Enlightenment thought, still remains valid. From the level of a current discussion on religion, the Enlightenment critique is often cited. Therefore, for example, Trias claims that a contemporary return to religion is caused by a weakening of the role of reason and, so to speak, by precisely discrediting the Enlightenment critique:

All this takes place against the horizon of a general crisis in the idea, or the ideal, of reason steadily forged and established by the West since the Enlightenment. It is time, then, to "take the bull by the horns" and not to be daunted by the magnitude of the crisis. This reason, solemnly proclaimed by our enlightened ancestors, was simply blind to these underlying religious strata, which are emerging today with such exceptional force and energy (Trias, 1998: 95).

\section{While Gianni Vattimo claims that}

Philosophy has rediscovered the plausibility of religion and can consequently approach the religious need of common consciousness independently of the framework of Enlightenment critique (Vattimo, 1998: 84).

Thus, philosophy could have "rediscovered the plausibility of religion" precisely by turning away from reason. He means that also by writing about the

idea of morality". And later: "the unconditional universality of the categorial imperative is evangelical” (Derrida, 1998: 10, 11).

19 The Reformation also had an influence on lessening of the role of cult and ritual: "The point of declaring that salvation comes through faith was radically to devalue ritual and external practice in favor of inward adherence to Christ as Savior" (Taylor, 2002: 9). When we refer these words to the moral concept of religion, we could say the same thing. We would just need to change the word "faith" into "good action" and "Christ as Savior" into "Christ as morality-giver". 
"framework of Enlightenment" - this is a framework of thought focused on reason.

However, the Enlightenment is called upon to sketch the background of the contemporary discussion on religion equally often, as it becomes a subject of critique because of the moral concepts of religion originated in that era. Aldo Giorgio Gargani claims that

The term "moralism" expresses the distortion responsible for the way an annunciation, a gospel, degenerates into a dogmatics of human behavior. But moralism is consequently also the loss of theological consciousness in its highest and richest sense, that is, as reflection, rational meditation of the annunciation and the exercise of doubt. Moralism, or religious experience to a code of behavioural prescriptions, lacks the love that sets theological enquiry alight (Gargani, 1998: 118).

Thus, moralism does not see the whole richness of a religious experience, of a sacrum experience. This concept is too narrow, too reductionistic. ${ }^{20}$ Often even so reductionistic that it disposes of religion completely, since - as Leszek Kołakowski puts it -

Whenever one tries to reduce religion to its normative consequences, to the acts of will and moral commitments, so often skips all that, what is specifically religious; it is not an interpretation, but a complete rejection of the language of sacrum (Kołakowski, 1982: 116).

The already mentioned Maurizio Ferraris seems less critical towards the moral concept of religion, however he sees the difficulty of reducing religion to morality and portraying Jesus only as a moral archetype:

Christ is not a mediator, but a great example of humanity, greater even than Socrates. The imitation of Christ is thus possible, but everything here hangs on the avoidance of deism in order to save a theism of some kind. The God that is too human is, in fact, not even useful. To be sure, the reduction of God to the moral God is functional to the religion itself; but it is an insidious functionality, in that it ultimately destroys religion, besieging it and finally overcoming it with alternative forms of morality and still more effective ideologies (Ferraris, 1998: 171).

${ }^{20}$ This could not be the case if we were to acknowledge the non-reductionistic interpretation of the Kantian philosophy of religion mentioned several times before. Yet, it seems that a great number of the contemporary authors (at least those cited here) do not treat Kant as a non-reductionist. However, if they were to admit his elevation of morality to the rank of religion, they would come to different conclusions. On the other hand, the often-made accusation (like the one made by Vattimo) towards the moral interpretation of religion does not focus on the reductionistic aspect, but on the purely rational treatment of religion which seems to be present in Kant's project independently from the matter of reductionism/ non-reductionism. 
On the basis of these words Ferraris interprets the Kantian concept of moral religion which strives, in his mind, to atheism (at this place Ferraris' words sound more critical, similar to those of Kołakowski):

The transition from churchgoing faith to pure religious faith is a movement towards the kingdom of God: the further one advances in secularization, the closer one gets to the kingdom. Here the religion of the heart arrives at atheism (Ferraris, 1998: 175).

On the grounds of contemporary philosophy there are almost no concepts of religion that would reduce it to morality or, like Kant - elevate morality to the rank of religion. That is, on the one hand, because of a thesis, proclaimed in our world, that religion reduced to the moral aspect becomes atheism, and on the other hand because of the theories focusing on the religious experience which began to appear already in the nineteenth century, to which belong: the thought of Søren Kierkegaard, Friedrich Daniel Ernst Schleiermacher and Rudolf Otto. ${ }^{21}$ One of the opponents of the moral, rational interpretation of religion was William James who also focused on the religious experience, but in a slightly different aspect. The turn towards an individual experience of sacrum in the philosophy of religion made moral interpretations of religion fade, since it was discovered that they are mostly in fact areligious, asacral. However, from the social point of view they represent a very interesting and socially beneficial "religion of being for others". But it is not - in the opinions of most contemporary thinkers something that would deserve to be called religion, only some sort of a moral system which either does not need God at all or reduces his role to a minimum. Kant alone proposed to act as if God was not present. However, it could be worth remembering about and developing the moral interpretation of religion (and still call it religion), because of its social and philosophical value. Also, it could be an interesting counter-concept to the religious experience theory and to some of the non-rational interpretations of religion as with certain kinds of mysticism.

Today one leaves the moral concept of religion and, in consequence, also the purely moral interpretation of Jesus. However, it seems that this important aspect is too often forgotten. In most cases the reflection focuses on the ontological or epistemological concerns related to Jesus. Whereas the Church still seems more likely to remain with the cult, ritual and moralization than with the moral

${ }^{21}$ The concept of a religious experience as the essence of religion was something completely new in the philosophy of religion. It also was interesting and strong enough, in contrast to the moral interpretation of religion, to be developed even in contemporary philosophy. The idea of religious experience focused on the irrational aspect of religion and at the same time constituted a critique of everything rational in religion thus - among others - also a critique of morality. Schleiermacher states, that: "religion neither seeks like metaphysics to determine and explain the nature of the Universe, nor like morals to advance and perfect the Universe by the power of freedom and the divine will of man. It is neither thinking nor acting, but intuition and feeling" (Schleiermacher, 1893: 277). 
teachings which are - independently from accepting them as the essence of religion or not - extremely important. It seems that also the apostles - who were accused of falsifying religion - were more focused on the experience of God, Jesus than on the morality that derived from his teachings. Thus, today neither the New Testament nor the apostles are accused of falsifying the teachings of Jesus. Whereas the Enlightenment critique brought much to the discussion on religion. Thanks to which contemporary thought could "escape" from reason, from morality and could turn itself towards a more - so to speak — mystical side of religion which is experiencing the sacrum;22 becoming closer to God by experiencing God himself, the community in which he appears, the world which is supposed to be an evidence of his presence, etc. The evaluation of this process (namely: leaving the moral interpretation aside and developing the feeling-oriented one) is not easy to conduct. But surely, this important Enlightenment concept should draw more attention in contemporary philosophy.

Many philosophers have called upon a return to the original sense of Jesus's message, his moral teachings. Thanks to a study of his life and thought they came to the conclusion that morality is the essence of religion, since morality is exactly what Jesus represents. Whereas the Church reduced religion to cult and ritual which are not - according to most of the mentioned thinkers - a means to be closer to God. Kant called this religion of Jesus (initial in its essence) "pure rational religion", Lessing named it a "New Order" or the "Eternal Gospel", whereas Feuerbach spoke of "universal love", but even earlier Rousseau had defended the thesis about "initial Christianity", and Locke, as well as Hume, had proposed "natural religion".

As we can see, it is an immense tradition of thought developed mostly in the Enlightenment, however its beginnings can be found in the theory of Erasmus and its end - a long time after Kant. In response to this moral and rational interpretation of religion is the theory focused on religious experience which stresses not the role of reason but of the feeling. In spite of that, the moral concept of religion is regrettably not developed anymore. It remains as a background for the whole discussion on religion and even for just that particular reason (if we were to diminish the role and importance of the moral interpretation), it is worth to - even for a minute - focus on the Enlightenment critique and see in what ways philosophers were led by their own thoughts.

${ }^{22}$ It is worth mentioning that maybe some of the moral religious concepts like Kant's (if we acknowledge the claim that he was not a reductionist) could be compatible with this contemporary view of religion. It would be interesting to see the conglomerate of a moral and mystical interpretation of religion, in which morality would become the subject of some kind of a transcendental feeling. This problem, however, in spite of its importance, is not the subject of this paper. It is only mentioned so it can be reflected on and maybe taken into serious consideration. 


\section{BIBLIOGRAPHY}

Axinn, S. (1968). Kant on Judaism. The Jewish Quarterly Review, 59(1), 9-23.

Borowski, H. (1986). Kantowska filozofia religii. Warszawa: Książka i Wiedza.

Carmichael, P.A. (1973). Kant and Jesus. Philosopby and Phenomenological Research, 33(3), 412-416.

Chlewicki, M. (2011). Kant, Fichte i wczesny Hegel o religii moralnej. Przeglad Filozoficzny Nowa Seria, 1(77), 219-232.

Chlewicki, M. (2012). Kant a problem filozofii religii. Bydgoszcz: Wydawnictwo Uniwersytetu Kazimierza Wielkiego.

Derrida, J. (1998). Faith and knowledge (pp. 1-79). In: J. Derrida \& G. Vattimo (Eds.). Religion. Oxford: Polity Press.

Erasmus (1913). The praise of folly. (J. Wilson, Trans.). Oxford: Clarendon Press.

Ferraris, M. (1998). The meaning of being as a determinate ontic trace (pp. 170-200). In: J. Derrida \& G. Vattimo (Eds.). Religion. Oxford: Polity Press.

Feuerbach, L. (1881). The essence of Christianity. (M. Evans, Trans.). London: Trübner \& Co.

Firestone, C.L. \& Jacobs, N.A. (2008). In defense of Kant's religion. Indiana University Press.

Gargani, A.G. (1998). Religious experience as event and interpretation (pp. 111-136). In: J. Derrida \& G. Vattimo (Eds.). Religion. Oxford: Polity Press.

Kant, I. (2009). Religion within the bounds of bare reason. (W.S. Pluhar, Trans.). Cambridge: Hackett Publishing Company, Inc.

Kołakowski, L. (1982). Religion, if there is no God: On God, the devil, sin, and other worries of the so-called philosophy of religion. New York: Oxford University Press.

Kroński, T. (1966). Kant. Warszawa: Wiedza Powszechna.

Lessing, G.E. (1908). The education of the buman race. (J.D. Haney, Trans.). New York: Teachers College Columbia University.

Munk, R. (2006). Mendelssohn and Kant on Judaism. Jewish Studies Quarterly, 13(3), 215-222.

Otto, R. (1936). The idea of the Holly. (J.W. Harvey, Trans.). Oxford: Oxford University Press.

Palmquist, S.R. (1992). Does Kant reduce religion to morality? Kant-Studien, 83(2), 129-148.

Palmquist, S.R. (2012). Could Kant's Jesus be God?. International Philosophical Quarterly, 52(4), 421-437.

Palmquist, S.R. (2016). Comprehensive commentary on Kant's religion within the bounds of bare reason. Hoboken: Wiley Blackwell.

Pasternack, L.R. (2013). Routledge philosophy guidebook to Kant on religion within the boundaries of mere reason. London: Routledge.

Schleiermacher, F.D.E. (1893). On religion: Speeches to its cultured despisers. (J. Oman, Trans.). London: Kegan Paul, Trench, Trübner \& Co.

Taylor, Ch. (1999). A Catholic modernity. Oxford: Oxford University Press.

Taylor, Ch. (2002). Varieties of religion today. Cambridge: Harvard University Press.

Thomas, S.B. (1970). Jesus and Kant: A problem in reconciling two different points of view. Mind New Series, 79(314), 188-199.

Trias, E. (1998). Thinking religion: The symbol and the sacred (pp. 95-111). In: J. Derrida \& G. Vattimo (Eds.). Religion. Oxford: Polity Press.

Vattimo, G. (1998). The trace of the trace (pp. 79-95). In: J. Derrida, G. Vattimo (Eds.). Religion. Oxford: Polity Press.

Vitiello, V. (1998). Desert, ethos, abandonment: Towards a topology of religion (pp. 136-170). In: J. Derrida \& G. Vattimo (Eds.). Religion. Oxford: Polity Press.

Wszołek, S. (2004). Wprowadzenie do filozofii religii. Kraków: Wydawnictwo WAM. 
